\title{
DESCRIPTION OF TWO NEW CERCARIAE (AN ECHINOSTOME CERCARIA AND A XIPHIDIOCERCARIA) PROCURED FROM BIOMPHALARIA PFEIFFERI (KRAUSS) FROM NIGERIA
}

\section{By}

\author{
FOUAD YOUSIF ${ }^{1 *}$, MAGDA AYOUB ${ }^{1}$, MENERVA TADROS $^{1}$, \\ SAMIA EL BARDICY ${ }^{1}$ AND SIMON ABOLARINWA ${ }^{2}$
}

Department of Environmental Research and Medical Malacology ${ }^{1}$, Theodor Bilharz Research Institute, Imbaba, Egypt and Department of Biological Sciences ${ }^{2}$, Federal University of Technology. Minna, Niger State, Nigeria ('Correspondence: E-mail: fouad-yousif@hotmail.com)

\begin{abstract}
During parasitological examination of Biomphalaria pfeifferi snails obtained from Niger state (Nigeria), 2 new types of cercariae were found. They are identified to the level of referring to the major group and described here for the first time. They were examined viable and stained with vital stains as well as fixed in $70 \%$ alcohol. They were drawn with a camera lucida and photographed. They are identified as an echinostome cercaria and a xiphidiocercaria. The echinostome is characterized by having a ventral sucker almost double in size the oral one. It has a semicircular structure located beyond the oral sucker. Three pairs of penetration glands are found at the anterior portion of the body. The number of collar spines is relatively large (44-46). The flame cells are $17 \times 2$ in number. Two main lateral excretory ducts extend anteriorly, form two typical echinostome loops then pass posteriorly to open together in a diverticulated excretory vesicle. Its tail is relatively long and flattened with 3 fin folds. The tail $(640 \mu \mathrm{m})$ is longer than the body $(475 \mu \mathrm{m})$.

The xiphidiocercaria belongs to the "ornatae" group. It is relatively small $(180.5 \times 110 \mu \mathrm{m})$ with a long stylet $(30 \mu \mathrm{m})$. Its oral sucker is one and half times the size of the ventral sucker. Two excretory ducts extend posteriorly in both sides and become dilated and unite to open in a circular excretory vesicle. Tail is slender shorter than the body and has a dorso-ventral fin fold. Key words: Echinostome cercaria, xixphidiocercaria, Biomphalaria pfeifferi, Nigeria.
\end{abstract}

\section{Introduction}

This paper gives morphological description of two newly recorded cercariae procured from Biomphalaria pfeifferi snails obtained from a man-made lake in Nigeria. This snail is largely distributed known to act as intermediate host of Schistosoma mansoni in many African countries (Meuleman, 1971; Woolhouse and Chandiwana, 1989; Ndifon and Yahaya, 1990; Ayanda, 2009). It also acts as intermediate host of some other trematodes (Loker et al, 1981; Frandsen and Christensen, 1984; Nkwengulila and Kigadye, 2005; Ahmed et al, 2006).

The present two cercariae are identified to the level of referring each to the major group of cercariae it belongs according to Richard and Brygoo (1978), Jourdane and Kulo, (1981) and Frandsen and Christensen
(1984). They proved to be an echinostome cercaria and an ornatae xiphidiocercaria. A review of literature showed that some studies on the type, distribution and prevalence of echinostome cercariae and xiphidiocercariae in Africa were given by Loker et al. (1981) and Frandsen and Christensen (1984). It appears from these studies that $B$. pfeifferi acts as intermediate host of some echinostomes such as Echinostoma caproni in Madagascar (Richard and Brygoo, 1978) and E. togoensis in Togo (Jourdane and Kulo, 1981).

The xiphidiocercariae were reported to be the most prevalent trematodes produced by Bomiphalaria pfeifferi and B. sudanica (Nkwengulila and Kigadye 2005). Frandsen and Christensen (1984) in studying African cercariae classified Xiphidiocercariae into 
three types: ornatae, virgulate and armatae xiphidiocercariae. The ornatae cercariae are characterised by a dorso-ventral finfold, without virgula organ and ventral sucker smaller than the oral one. The virgulate xiphidiocercariae are characterized by the absence of finfolds, presence of bilobed virgula organ in the region of the oral sucker and ventral sucker smaller than oral sucker. The armatae xiphidiocercariae are characterized by the absence of finfolds and virgulae, equal oral and ventral suckers or ventral sucker larger than the oral sucker.

\section{Material and Methods}

Biomphalaria pfeifferi (Krauss) snails examined here were found in a man-made lake from a village called Bosso, a suburb of Minna, Niger state, Nigeria. It was collected in March, 2013 which coincided with the peak of the hot dry season in northern Nigeria. The snails were transported alive to the Schistosome Biological Supply Centre (SBSC) at Theodor Bilharz Research Institute (TBRI), Cairo, Egypt, where they were maintained for 8 weeks under laboratory conditions. The snails were examined twice weekly for natural trematode infection. Thus, appropriate number of snails (10 snails) were placed in glass containers with dechlorinated tap water and exposed to fluorescent light for one hour to induce cercarial emergence. The emerged cercariae were collected with a fine glass pipette in small petri dishes in each case. They were examined alive after staining them with vital stains, (Neutral red and Nile blue sulphate) using a light microscope. The cercariae were then drawn using of a camera lucida. They were also fixed under cover slips using $70 \%$ alcohol. Twenty specimens of each type of cercariae were measured and the dimensions of the body, tail and suckers were determined in millimeter. Photos of each type of cercariae were taken. The two cercariae procured from B. pfeifferi are identified to an echinostome and a xiphidiocercaria depending on the guide of identification of cercariae from African freshwater snails given by Frandsen and Christensen (1984).

\section{Results}

The Echinostome cercaria (Fig. 1): This type of cercariae is recognized by its characteristic movement, it swims through the water while curving the body ventrally. After swimming for some hours (3-6h) it sinks to the bottom and dies. This echinostome cercaria has a relatively large body, pear shaped, 330-620 $\mu \mathrm{m}$ long and 150-350 $\mu \mathrm{m}$ wide. The body is opaque whitish in colour, and has a characteristic projecting collar carrying one row of similar triangular spines; formed of 44-46 spines each measures 10-12 $\mu \mathrm{m}$ in length. This cercaria is provided with 2 circular suckers, an oral subterminal sucker (40-60 $\mu \mathrm{m}$ in diameter) and a much larger postequatorial ventral one or acetabulum $(80-120 \mu \mathrm{m}$ in diameter). A semicircular structure is observed at the posterior side of the oral sucker.

There is a relatively short prepharynx and

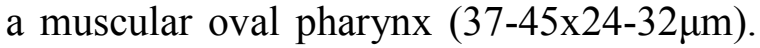
It leads into a relatively long narrow oesophagus $(10-14 \mu \mathrm{m})$ which bifurcates in front of the acetabulum into two intestinal caeca. These caeca extend posteriorly till the level of excretory vesicle.Numerous cystogenous glands are distributed equally below the body surface extending from the level of pharynx till the posterior end of the body. These glands are opaque filled with granules. Three pairs of penetration glands are distinguished at the anterior portion of the body and open on the oral sucker by 6 pores which are visible on the anterior margin. The genital primordium is formed of one mass of cells and lies between the acetabulum and the excretory vesicle. The flame cells are generally inconspicuous, hardly distinguished to be $17 \times 2$ in number. Two main lateral excretory ducts extend anteriorly to the region of the pharynx to form two typical echinostome loops then pass posteriorly to open together at the same point on the anterior side of the excretory vesicle. They are dilated at the middle of the body containing 
numerous relatively large refractive excretory granules (40-80) in number measuring $0.012 \mathrm{~mm}$ in diameter. Much narrower ductules from the flame cells are observed opening into that portion of the excretory duct. The excretory vesicle is diverticulated in outline and lies at the posterior end of body opens to the exterior through the excretory pore located at the junction between the body and the tail.

The tail is unforked flattened and rolled measuring about two times the length of the body $(630-750 x 80-100 \mu \mathrm{m})$. It is finger-like at its terminal portion. It carries three later fin folds: two are anterior at the middle of the tail and one nearer to the posterior end. The caudal excretory duct is extending along one-sixth of the tail length before bifurcating giving obliquely running lateral branches

Redia: The young rediae are whitish in colour and become pink after maturating. The redia has a distinct collar and two locomotory processes at the posterior third of body. A birth pore is visible at the anterior third of the body. The mouth leads into a well-developed muscular pharynx followed by a long sac-like gut which extends to about the middle of the body. The pharynx is oval measures $(40-50 \times 17-23 \mu \mathrm{m})$ (Fig. 1,C). The young redia contains many germ cell balls $(70-100 \times 50-80 \mu \mathrm{m})$. The mature rediae (1100-1400x290-350 $\mu \mathrm{m})$ contain germ balls and small rediae.

The xiphidiocercaria (Fig. 2): The second type of cercariae obtained from $B$. pfeifferi is a xiphidiocercaria. This cercaria swims actively with the help of its tail lashing violently in all directions in the water. After swimming for some hours (6-8h) it sinks to the bottom and dies. This xiphidiocercaria is characterized by the presence of a welldeveloped conspicuous stylet on its oral sucker. The stylet has a sharp anterior tip and a posterior broad rounded base. It measures $30 \mu \mathrm{m}$ in length and attains its largest width posteriorly $(5 \mu \mathrm{m})$. The eye spots are absent and the excretory vesicle is thin-walled. From a total of 893 specimens of Biomphalaria pfeifferi 74 snails were naturally infected with this type of xiphidiocercariae.

The body of the cercaria is oval in shape (170-200x110-120 $\mu \mathrm{m})$, provided with two strong circular suckers. The oral sucker is subterminal $(50-54 \mu \mathrm{m})$ and is larger than the ventral sucker (31-37 $\mu \mathrm{m})$. The ventral sucker is located behind the middle of the body. The pharynx is relatively small (15$18 \times 10-17 \mu \mathrm{m})$ and preceded by a prepharynx. It leads into a short and narrow oesophagus which bifurcates near the anterior border of the ventral sucker into two intestinal caeca that terminate at the anterior side of the ventral sucker.

Prominent cytogenous glands extend from the oral sucker to the posterior end of the body. A pair of large unicellular vesicular glands is also conspicuous anteriorly on either side of the oral sucker. Three pairs of relatively large penetration glands lie near the middle of the body, in front of the ventral sucker. From each gland, a long duct passes forward to open at the anterior end of the body, lateral to the stylet. The excretory system comprises two excretory ducts which extend posteriorly from the anterior end of the body, become convoluted then dilated on both sides of the ventral sucker, to unite and open on the anterior side of a circular excretory vesicle.

This cercaria has a heavy cuticle which bears very fine, backward pointing spines, so arranged as to make a cross-hatch pattern over the entire body.

The tail is slender $(120-150 \times 50-54 \mu \mathrm{m})$ and has a dorso-ventral fin fold. This fin extends from mid of dorsal side of the tail then around its tip for the posterior a quarter of the ventral side. This cercaria develops within sausage shape sporocysts.

\section{Discussion}

In present study, one echinostome cercaria and one xiphidiocercaria were procured from Biomphalaria pfeifferi snails collected from a man-made lake in Nigeria. As far as can be ascertained, these two cercariae 
are described here for the first time. The present echinostome cercaria is different from other cercariae of the same group previously reported from this and other planorbid snails in Africa (Tab. 1). These cercariae are Echinostoma liei, E. revolutum and Echinoparyphium recurvatum which use Biomphalaria alexandrina and Bulinus truncatus snails in Egypt respectively as intermediate host (Moravec et.al, 1974; Yousif and Haroun,1986), Cercaria ogunis from Bulinus globosus in West Africa (Dönges, 1977), E. caproni from B. pfeifferi in Madagascar (Richard and Brygoo, 1978), E. togoensis from B. pfeifferi in Togo (Jourdane and Kulo, 1981), 4 echinostomes in Tanzania (Loker et al,1981), Echinostoma in $\mathrm{Ni}$ geria (Ndifon andYahaya,1990) are not described.

The present echinostome cercaria differs from those cercariae in morphological features such as body and tail dimensions and shape of excretory vesicle. However, the present echinostome cercaria resembles Cercaria ogunis (Dönges, 1977) in the number of collar spines but is different in number of the fin folds. It differs from Echinostoma revolutum, E. liei and E. togoensis by possessing 44-46 collar spines vs 37 spines in E. togoensis cercariae. E. liei and E. revolutum suckers's size are very close while the ventral sucker of present cercaria is almost double the size of the oral sucker (Yousif and Haroun, 1986, and Moravec et al., 1974). The present cercaria has 3 fin folds while E. liei and E. revolutum have 3 and 5 pairs of fin folds respectively (Yousif and Haroun, 1986). Echinopary-phium recurvatum lakes fin folds and is procured from $\mathrm{Bu}$ linus truncatus and Planorbis planorbis with 40-45 collar spines arranged in double rows (Moravec et al, 1974). The fattened tail and characteristic structure beyond the oral sucker in the present cercaria confirm that it is a new species.

The characteristics that could be used for the classification of xiphidiocercariae were reviewed by Nasir (1972). These character- istics included flame cells formulae, body form, shape of stylet, presence or absence of finfolds, structure of excretory system and number and location of penetration glands. However, Frandsen and Christensen (1984) in identification of African xiphidiocercariae classified them to three groups Ornatae xiphidiocercaria which characterized by presence of dorso-ventral fin and ventral sucker is smaller than oral sucker, virgulate which has no fin and presence of bilobed virgula organ in the region of oral sucker and armatae xiphidiocercariae characterized by absent of virgula organ and fin folds. Therefore, the present xiphidiocercaria is classified as ornatae depending on presence of fin fold of tail and absent of virgula organ. Some studies dealt with type and prevalence of cercariae in Africa but without descriptions (Loker et al, 1981; Ndifon and Yahaya, 1990; Ahmed et al, 2006). Some xiphidiocercariae are reported to procure from planorbid snails in Africa as a xiphidiocercaria procured from Bulinus truncatus belong to armatae group after Frandsen and Christensen (1984) described by Rys̃avỹ et al. (1975). Wanas et al. (1993) described Lepoderma ramliamum, (Looss, 1896) cercaria from B. truncatus, Khalifa et al. (1997) described another xiphidiocercaria procured from the same snail. King (2001) described 3 xiphidiocercaria all belong to armatae group. A comparison between these xiphidiocercariae and the present one (Tab. 2) showed that the latter differs considerably from them in several aspects as body dimensions, number shape, position of penetration glands, shape of stylet, excretory vesicle form and presence of fin fold at tail end.

\section{Conclusion}

The present two cercariae belonging to the echinostome and xiphidiocercariae groups proved to be new and described here for the first time. However, further studies are still needed to complete their life cycle for their final identification. 


\section{References}

Ahmed, MA, Ibrahim, N, Idris, MA, 2006: Laboratory studies on prevalence and cercarial rhythmus of trematodes from Khartoum State Sudan. Sultan Qaboos Univ. Med. J. 6, 2:65-9.

Ayanda, OI, 2009: Prevalence of snail vectors of schistosomiasis and their infection rates in two localities within Ahmadu Bello University (ABU) campus, Zaria, Kaduna State, Nigeria. J. cell Animal Biol. 3, 4:58-61.

Dönges, J, 1977: Cercaria ogunis n. sp. (Echinostomatidae) aus Bulinus globosus in West Africa. Z. Parasitenk. 52:297-309.

Frandsen, F, Christensen, N, 1984: An introductory guide to the identification of cercariae from Africa freshwater snails with special reference to cercariae of trematode species of medical and veterinary impor- tance. Acta Tropica 41:181-202.

Jourdane, S, Kulo, S, 1981: Experimental study of the life cycle of Echinostoma togoensis n. sp., a larval parasite of Biomphalaria pfeifferi in Togo. Ann. Parasitol. Hum. 56, 5:477-88.

Khalifa, RM, Saad, AI, Maher, NH, 1997: Studies on some freshwater cercariae from Aswan, Egypt: Part 1. J. Egypt Ger. Soc. Zool. 24, D:225-49.

King, PH, Van AS, JG, 2001: Cercaria shed by Bulinus tropicus (Krauss, 1848) in the free state South Africa. J. Africa Zool. 36:95-105.

Loker, S, Moyo, HG, Gardner, SL, 1981: Trematode-Gastropod association in nine nonlacustrine habitats in the Mwanza Region of Tanzania. Parasitol. 83:381-99.

Meuleman, E, 1971: Host-prasite interrelationships between the freshwater pulmonate $B i$ omphalaria pfeifferi and trematode Schistosoma mansoni. Netherlands J. Zool. 22, 4: 355-427.
Moravec, F, Barus, V, Rysavy, B, Yousif, F, 1974: Observations on the development of two Echinostomes, Echinoparyphium Recurvatum and Echinostoma revolutum, the antagonists of human schistosomes in Egypt. Fol. Parasitol. 21:107-26.

Nasir, P, 1972: Some aspects of xiphidiocercarial classification. Zoologischer An zeiger 189: 382-92.

Ndifon, GT, Umar-Yahaya, A, 1990: Remove from marked records cercariae of freshwatersnails in Kano, Nigeria. Nigerian J. Parasitol. 9, 11:69-75.

Nkwengulila, G, Kigadye, ESP, 2005: Occurrence of digenean larvae in freshwater snails in Ruvu Basin, Tanzania. Tanz. J. Sci. 31, 2:23-30.

Richard, J, Brygoo, ER, 1978: Life cycle of the trematode Echinostoma caproni (Richard, 1964) (Echinostomatidae). Ann. Parasitol. Hum. 53, 3:265-75.

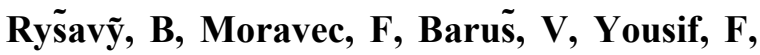
1975: Some helminthes of Bulinus truncatus and Biomphalaria alexandrina from the irrigation system near Cairo. Fol. Parasitol. 21:97-105.

Wanas, MQA, Abu-Senna, FM, Al-Sha-reef, AMF, 1993: Studies on larval digenetic trematodes xiphidiocercariae from some Egyptian fresh water snails. J. Egypt. Soc. Parasitol. 23, 3: 829-50.

Woolhouse, MEJ, Chandiwana, SK, 1989: Spatial and temporal heterogeneity in population dynamics of Bulinus globosus and Biomphalaria pfeifferi and in epidemiology of their infection with schistosomes. Parasitol. 98:21-34.

Yousif, F, Haroun N, 1986: Intramolluscan development of Echinostoma liei (Tramatoda: Echinostomatidae) in its snail host Biomphalaria alexandrina. J. Egypt Soc. Parasitol. 16, 1:12740. 


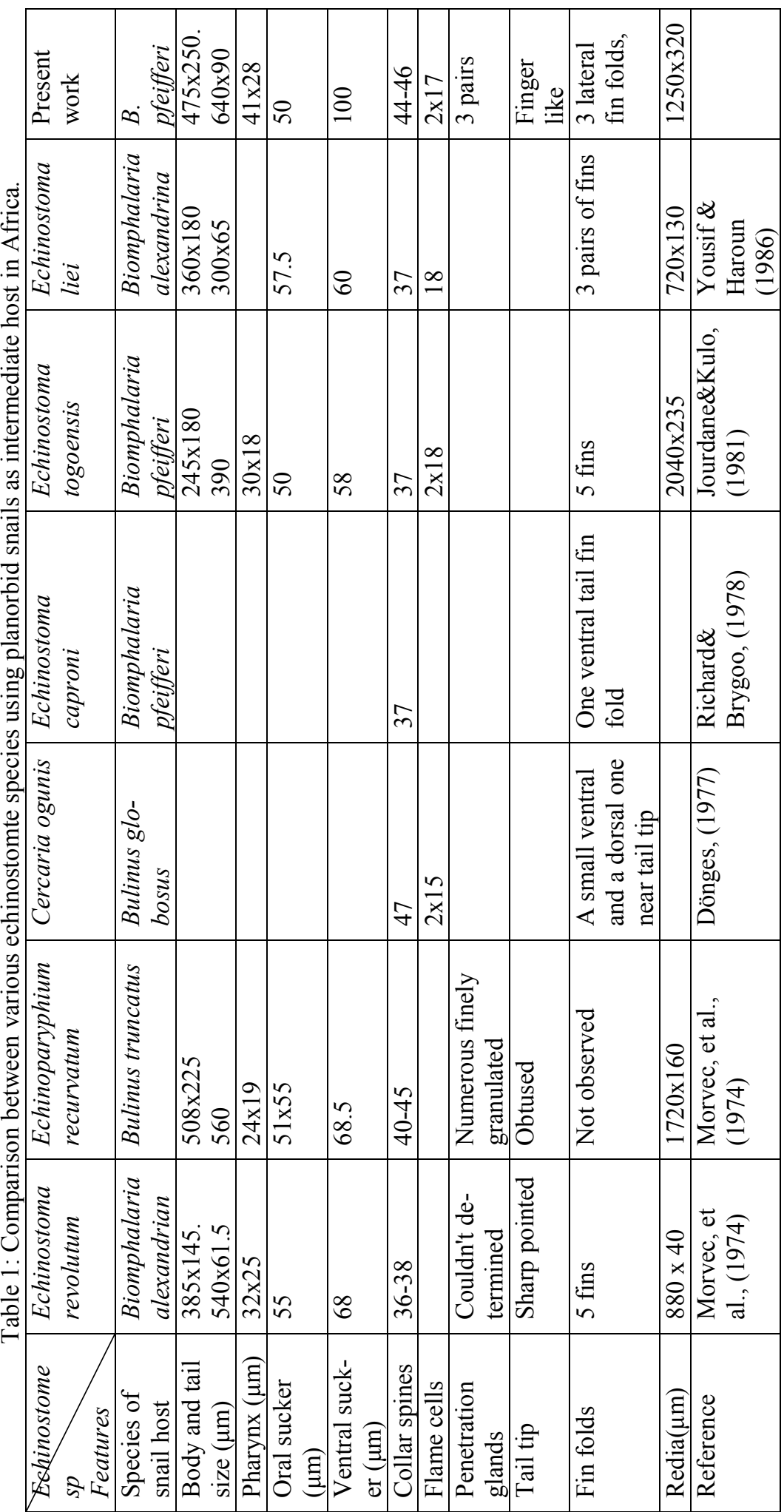



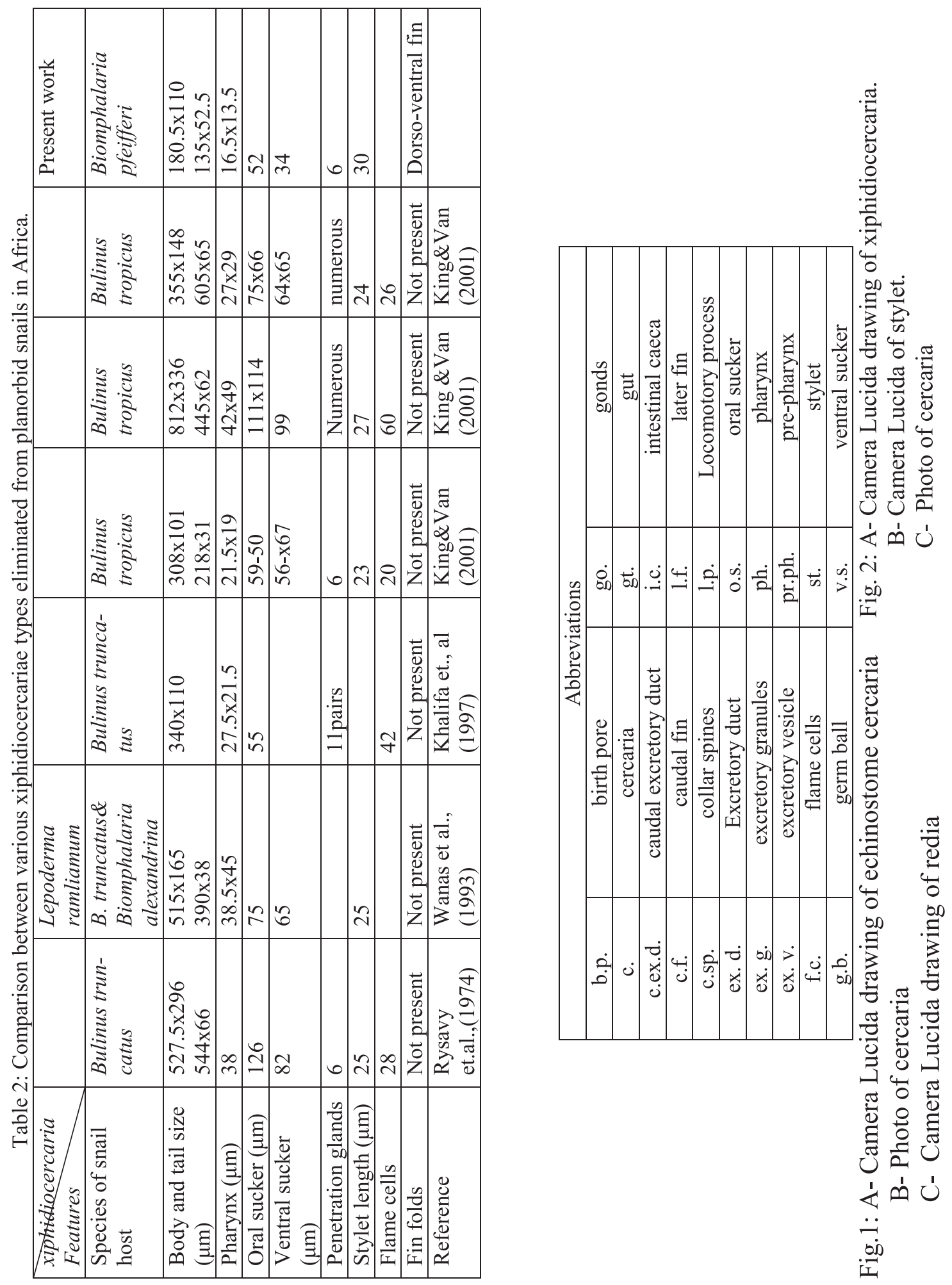

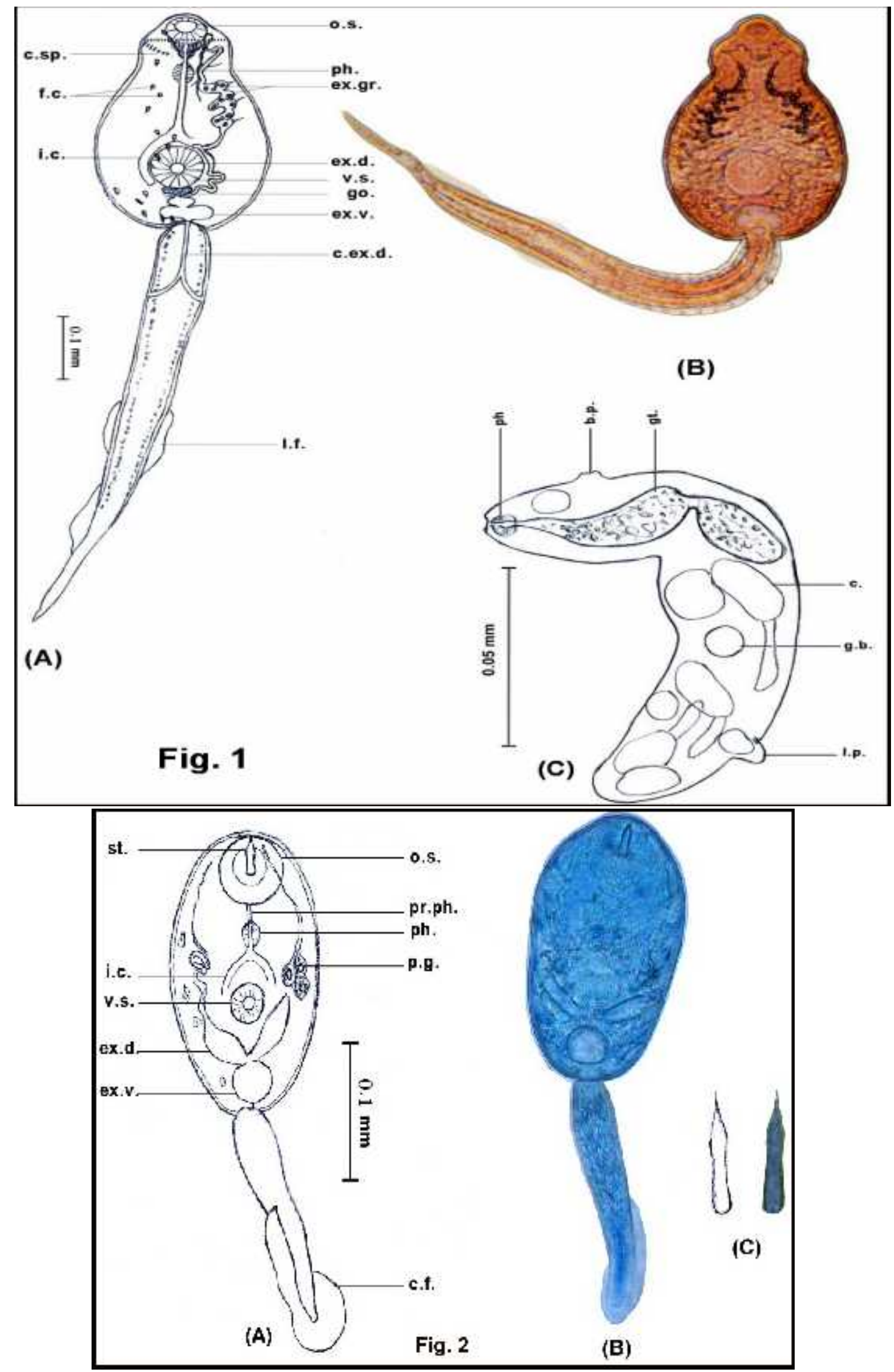